\title{
PENGARUH PENDAPATAN TERHADAP KONSUMSI DAGING DAN TELUR DI KECAMATAN SIAU BARAT KABUPATEN KEPULAUAN SIAU TAGULANDANG BIARO
}

\author{
Irgin. V. Badoa*, A.H.S. Salendu, F.H. Elly dan P.O.V. Waleleng \\ Fakultas Peternakan Universitas Sam Ratulangi, Manado, 95115
}

\begin{abstract}
ABSTRAK
Masyarakat pesisir adalah masyarakat yang berpenghasilan rendah, mengakibatkan kecenderungan untuk mengkonsumsi produk peternakan juga rendah. Kecamatan Siau Barat merupakan salah satu wilayah yang ada di Kabupaten Kepulauan Siau Tagulandang Biaro yang terletak di daerah pesisir pantai. Mayoritas penduduknya bekerja sebagai petani dan nelayan, sehingga dalam mengkonsumsi daging dan telur, tentu saja masyarakat menyesuaikan dengan pendapatan yang diperoleh. Tujuan penelitian adalah untuk mengetahui pengaruh pendapatan terhadam konsumsi daging dan telur. Penentuan sampel desa dilakukan secara Purposive Sampling

Nilai ini masih lebih tinggi dibandingkan dengan hasil penelitian Weol (2014) yaitu Rp. 108.257. Rata-rata konsumsi daging/kapita/tahun di Kecamatan Siau Barat sebesar 7,72 kg/kapita/tahun. Konsumsi sebesar $7,72 \mathrm{~kg}$ terdiri atas daging ayam sebesar 4,84 kg/kapita/tahun dan daging babi sebesar 2,88 kg/kapita/tahun. Sedangkan ratarata konsumsi telur $/ \mathrm{kg} / \mathrm{kapita} / \mathrm{tahun}$ sebesar $1,49 \mathrm{~kg} / \mathrm{kapita} / \mathrm{tahun}$. Hasil penelitian menunjukkan bahwa pendapatan keluarga berpengaruh nyata terhadap konsumsi daging ayam, daging babi dan telur di Kecamatan Siau Barat Kabupaten Kepulauan Siau Tagulandang Biaro.
\end{abstract} yaitu desa/kelurahan yang memiliki jumlah penduduk terbanyak dan berada di pesisir pantai. Penelitian dilaksanakan di Desa Pelingsawang, Peling dan Kelurahan Paniki. Metode pengumpulan data menggunakan metode survey. Data yang digunakan adalah data primer dan sekunder. Penentuan responden berdasarkan Simple Random Sampling. Jumlah responden sebanyak 41 responden. Variabel yang diukur adalah jumlah konsumsi daging, jumlah konsumsi telur dan pendapatan. Metode analisis yang digunakan adalah analisis regresi sederhana.

Berdasarkan hasil penelitian, jumlah pendapatan responden secara keseluruhan adalah Rp. 136.660.000 dengan rata-rata 3.333.171/rumahtangga/bulan. Jumlah konsumsi daging ayam sebesar $58,5 \mathrm{Kg} /$ bulan, daging babi 27,5 Kg/bulan dan telur 17,4 $\mathrm{Kg} /$ bulan. Rata-rata pengeluaran responden untuk mengkonsumsi daging dan telur sebesar Rp. 122.195 atau $3,67 \%$ dari pendapatan keluarga.

*Korespondensi (cooresponding author) :

Email : irginbadoa@ rocketmail.com
Kata Kunci: Pendapatan, Konsumsi, Daging, Telur

\section{ABSTRACT}

EFFECT OF INCOME ON MEAT AND
EGG CONSUMPTION IN WEST
DISTRICT OIAU
TAGULANDANG BIARO REGENCY

Generally, coastal farmer community have low income causing consumptions of livestock product are low. West Siau district was including in the Siau Tagulandang Biaro Island regency as the coastal area. Majority of the population of this regency were household farmer and fisher men, causing consumption of livestock product depended on their income. Objective of this study was to evaluate the effect of income on meat and egg consumption in West Siau district. Samples of villages were defined using purposive sampling method, referring to villages with high population staying on the coastal area including villages of Pelingsawang, Peling and Paniki. Data were collected using survey method including 
primary and secondary data. Household farmers were defined based on simple random sampling with the total of 41 persons. Variables observed were total meat consumption, total egg consumption and income per capita. Data were analyzed by simple regression analysis. Results showed that total income of household farmer were IDR $136,660,000$ with the average of IDR $3,333,171$ per household farmer per month. Total chicken meat, pork and egg consumptions were $58.5 \mathrm{~kg}, 27.5 \mathrm{~kg}$ and 17.4 $\mathrm{kg}$ per month, respectively. Average investment to consume meat and eggs were IDR 122,195 or 3.67 percents of the family income. Average meat consumption at West Siau district were $7.72 \mathrm{~kg}$ per capita per year, consisted of chicken meat and pork of $4.84 \mathrm{~kg}$ and $2.88 \mathrm{~kg}$ per capita per year, respectively. Average of egg consumption were $1.49 \mathrm{~kg}$ per capita per year. Therefore, income of the family significantly affected meat and egg consumption in West Siau district of the Siau Tagulandang Biaro regency.

Keywords: Income, meat and egg consumption, Siau district.

\section{PENDAHULUAN}

Konsumsi protein hewani sesuai dengan standar gizi yang ditetapkan berdasarkan pembahasan Widya Karya Pangan dan Gizi tahun 2004, norma gizi protein hewani adalah 15 gram/kapita/hari. Standar kebutuhan protein hewani diharapkan 9 gram/kapita/hari berasal dari komoditas perikanan sedangkan sisanya 6 gram/kapita/hari berasal dari komoditas peternakan. Konsumsi sebesar 6 gram/kapita/hari setara dengan $10,3 \mathrm{~kg}$ daging/kapita/tahun, $\quad 6,5 \quad \mathrm{~kg}$ telur/kapita/tahun dan $\quad 7,2 \quad \mathrm{~kg}$ susu/kapita/tahun (Dinas Pertanian dan Peternakan, 2011).

Masyarakat pesisir adalah masyarakat yang berpenghasilan rendah, mengakibatkan kecenderungan mengkonsumsi produk peternakan juga rendah. Kecamatan Siau Barat merupakan salah satu wilayah yang ada di Kabupaten Kepulauan Siau Tagulandang Biaro yang terletak di daerah pesisir pantai. Mayoritas masyarakatnya bekerja sebagai petani dan nelayan, hanya sebagian kecil yang berprofesi sebagai Pegawai Negeri Sipil dan pedagang. Dalam mengkonsumsi daging dan telur, tentu saja masyarakat menyesuaikan dengan tingkat pendapatan yang diperoleh. Hasil penelitian Pontoh (2011) menunjukkan bahwa besarnya tingkat pendapatan yang diterima nelayan berpengaruh pula terhadap besarnya tingkat konsumsi nelayan di Kecamatan Tenga.

Berdasarkan latar belakang, maka yang menjadi permasalahannya yaitu: Bagaimana pengaruh pendapatan terhadap konsumsi daging dan telur di Kecamatan Siau Barat dan tujuan penelitian adalah untuk mengetahui pengaruh pendapatan terhadap konsumsi daging dan telur di Kecamatan Siau Barat. 


\section{METODE PENELITIAN}

Penelitian ini dilaksanakan di Kecamatan Siau Barat Kabupaten Kepulauan Siau Tagulandang Biaro. Waktu pelaksanaan penelitian selama satu bulan yaitu mulai bulan Desember 2014 sampai Januari 2015. Metode penelitian menggunakan metode survey. Data yang digunakan yaitu data primer dan sekunder. Data primer diperoleh langsung dari responden melalui wawancara dengan menggunakan daftar pertanyaan/kuosioner. Data sekunder diperoleh dari instansi yang terkait yaitu Dinas Pertanian dan Peternakan SULUT, Badan Pusat Statistik dan Kantor Kecamatan Siau Barat.

Penentuan lokasi secara cacah lengkap yaitu desa yang berada di daerah pantai. Untuk penentuan sampel desa dilakukan secara Purposive Sampling yaitu desa dan kelurahan yang memiliki jumlah penduduk yang paling banyak dan berada di pesisir pantai. Dari 9 desa dan 3 kelurahan, dipilih desa Pelingsawang, Peling dan Kelurahan Paniki. Tiap desa/kelurahan ditentukan jumlah responden secara Simple Random Sampling dari jumlah KK, sehingga responden yang diambil sebanyak 41 responden.

Variabel penelitian dan pengukuran dalam penelitian ini yaitu: (a) Konsumsi daging yaitu jumlah daging mentah yang dihasilkan sendiri maupun dibeli dan dikonsumsi selama 1 bulan oleh seluruh anggota keluarga, diukur dalam satuan $\mathrm{Kg} /$ bulan; (b) Konsumsi telur yaitu jumlah telur yang dihasilkan sendiri maupun dibeli dan dikonsumsi selama 1 bulan oleh seluruh anggota keluarga, diukur dalan satuan $\mathrm{Kg} / \mathrm{bulan}$; (c) Pendapatan yaitu jumlah penerimaan seluruh anggota keluarga selama 1 bulan, diukur dalam satuan Rp/bulan. Analisis data yang digunakan dalam penelitian adalah Analisis Regresi Sederhana (Akbar dan Usman, 2000) dengan persamaan $C_{i}=a+$ $b Y_{i}+e_{i}$.

\section{HASIL DAN PEMBAHASAN}

Besarnya pendapatan keluarga sangat menentukan besarnya konsumsi produk ternak (Soedjana, 1996). Penelitian Giang (2013) menunjukkan bahwa terdapat hubungan yang erat dan positif antara tingkat pendapatan dengan pola konsumsi.

Hasil penelitian menunjukkan bahwa pendapatan responden bervariasi yaitu terendah adalah Rp. 1.200 .000 per bulan, sedangkan yang tertinggi adalah $\mathrm{Rp}$. 8.500.000 per bulan. Jumlah pendapatan responden secara keseluruhan adalah $\mathrm{Rp}$. 136.660.000 dengan rata-rata $\mathrm{Rp}$. 3.333.171/rumah tangga/bulan. Rata-rata pendapatan rumahtangga per bulan masih 
lebih tinggi dibanding hasil penelitian (Elly et al, 2013) yang menunjukkan bahwa rata-rata pendapatan rumahtangga masyarakat pesisir di Kabupaten Minahasa sebesar Rp 3.123.700 per bulan. Selain itu, rata-rata pengeluaran keluarga responden dalam mengkonsumsi daging dan telur sebesar Rp. 122.195 atau sebesar 3,67\% dari pendapatan keluarga.

Daging yang dikonsumsi oleh responden adalah daging ayam dan daging babi. Daging ayam dikonsumsi oleh 30 responden sebanyak 58,5 $\mathrm{kg} / \mathrm{bulan}$ sedangkan daging babi dikonsumsi oleh 32 responden sebanyak $27,5 \mathrm{~kg} /$ bulan. Jenis telur yang dikonsumsi masyarakat adalah telur ayam ras sebanyak 260 butir atau $17,4 \mathrm{~kg} /$ bulan yang dikonsumsi oleh 32 responden dan keluarganya.

Hasil penelitian menunjukkan, rata-rata konsumsi daging/kapita/tahun di Kecamatan Siau Barat sebesar 7,72 kg/kapita/tahun. Konsumsi sebesar 7,72 kg terdiri atas daging ayam sebesar 4,84 $\mathrm{kg} / \mathrm{kapita} /$ tahun dan daging babi sebesar $2,88 \mathrm{~kg} / \mathrm{kapita} / \mathrm{tahun}$. Sedangkan rata-rata konsumsi telur/kg/kapita/tahun sebesar $1,49 \mathrm{~kg} / \mathrm{kapita} / \mathrm{tahun}$.

Konsumsi daging sebesar 7,72 $\mathrm{kg} / \mathrm{kapita} / \mathrm{tahun}$ belum memenuhi standar target nasional yaitu sebesar 10,3 kg daging/kapita/tahun (Dinas Pertanian dan Peternakan SULUT, 2011). Kondisi ini menunjukkan bahwa konsumsi daging di Kecamatan Siau Barat sebesar 74,95\% berarti terdapat kekurangan 25,05\% dari yang dianjurkan. Hal ini diduga karena dalam penelitian ini ada asumsi jika mengkonsumsi daging pada saat ibadah/syukuran/rumah makan tidak dianalisis. Lokasi penelitian yang berada di daerah pesisir pantai juga menjadi alasan rendahnya konsumsi daging. Masyarakat cenderung mengkonsumsi sumber protein asal ikan karena mudah didapat. Selain itu ada masyarakat yang kurang mengkonsumsi daging karena alasan kesehatan.

Konsumsi telur di Kecamatan Siau Barat hanya sebesar $1,49 \mathrm{~kg} / \mathrm{kapita} / \mathrm{tahun}$ sedangkan standar yang dianjurkan Widya Karya Pangan dan Gizi adalah sebesar 6,5 $\mathrm{kg} / \mathrm{kapita} / \mathrm{tahun}$. Kondisi ini menunjukkan bahwa konsumsi telur di Kecamatan Siau Barat sebesar 22,92\% berarti terdapat kekurangan sebesar $77,08 \%$ dari jumlah yang dianjurkan. Hal ini diduga disebabkan karena tingkat pendapatan yang rendah, alasan kesehatan, serta rendahnya pengetahuan masyarakat tentang pentingnya protein asal ternak.

Menurut Cahyani(2008), kondisi pola konsumsi pangan masyarakat saat ini adalah ketergantungan konsumsi pangan masyarakat terhadap pangan sumber karbohidrat, khususnya beras masih sangat 
tinggi (lebih dari 60\%), sementara pangan hewani masih sangat rendah. Penelitian Yusri (2012) menunjukkan bahwa pendapatan adalah salah satu variabel yang signifikan pengaruhnya terhadap jumlah konsumsi daging ayam.

Hasil analisis regresi pengaruh pendapatan terhadap konsumsi daging ayam dinyatakan dalam persamaan (1):

$\mathrm{C}=-2,441+0,659 \mathrm{Y}$

Nilai a (intersep) sebesar - 2,441 yaitu titik awal persamaan yang berpotongan dengan sumbu $\mathrm{C}$ pada grafik dan nilai sumbu $\mathrm{Y}=0$. Artinya, tanpa adanya peningkatan pendapatan maka masyarakat mengurangi konsumsi daging ayam (C) sebesar 2,441 atau 0,002 kg.

Nilai koefisien regresi dari variabel pendapatan sebesar 0,659 (b) artinya bila pendapatan naik satu rupiah maka konsumsi daging ayam naik sebesar 0,659 gr atau $0,0006 \mathrm{~kg}$. Bila pendapatan naik sebesar Rp 1000 maka konsumsi daging ayam akan meningkat sebesar 659 gr atau $0,659 \mathrm{~kg}$.

Hasil uji statistik menunjukkan bahwa nilai $t_{\text {hitung }}$ yang diperoleh sebesar 4,201 taraf signifikan $t=0,000$. Uji $t_{\text {hitung }}>$ uji $t_{\text {tabel }}$ artinya secara statisik pendapatan berpengaruh nyata terhadap konsumsi daging ayam (ceteris paribus). Artinya semakin tinggi pendapatan maka kecenderungan mengkonsumsi daging ayam di Kecamatan Siau Barat akan meningkat. Hasil ini ditunjang oleh penelitian Osak (2014) yang menunjukkan bahwa pendapatan berpengaruh nyata terhadap konsumsi daging ayam.

Hasil analisis regresi pengaruh pendapatan terhadap konsumsi daging babi dapat dilihat pada persamaan (2):

$\mathrm{C}=1,448+0,358 \mathrm{Y}$

Nilai a (intersep) sebesar 1,448 yaitu titik awal persamaan yang berpotongan dengan sumbu $\mathrm{C}$ pada grafik dan nilai sumbu $\mathrm{Y}=0$. Artinya, walaupun responden dan keluarganya tidak memperoleh pendapatan tetapi konsumsi daging babi (C) per bulan sebesar 1,448 gr atau $0,001 \mathrm{~kg}$.

Nilai koefisien regresi dari variabel pendapatan sebesar 0,358 (b) artinya bila pendapatan naik satu rupiah maka konsumsi daging babi naik sebesar 0,358 gr atau $0,0003 \mathrm{~kg}$. Bila pendapatan $\mathrm{Rp}$ 1000 maka konsumsi daging babi akan naik sebesar $358 \mathrm{gr}$ atau $0,358 \mathrm{~kg}$.

Nilai $t_{\text {hitung }}$ yang diperoleh adalah 2,757 pada taraf siginfikan 0,010 . Uji t > $\mathrm{t}_{\text {tabel }}$ artinya secara statistik perubahan pendapatan berpengaruh nyata terhadap perubahan konsumsi daging (ceteris paribus). Artinya, semakin tinggi pendapatan maka kecenderungan untuk mengkonsumsi daging babi di Kecamatan Siau Barat akan meningkat. Hasil ini 
ditunjang oleh penelitian Ambat (2011) yang menunjukkan bahwa pendapatan berpengaruh nyata terhadap konsumsi daging babi. Hal ini sejalan dengan teori ekonomi bahwa semakin tinggi pendapatan maka konsumsi suatu barang akan semakin tinggi (Sugiarto et al, 2002).

Hasil analisis pengaruh pendapatan terhadap konsumsi telur dapat dilihat pada persamaan (3):

$\mathrm{C}=3,199+0,201 \mathrm{Y}$

Nilai a (intersep) sebesar 3,199 yaitu titik awal persamaan yang berpotongan dengan sumbu $\mathrm{C}$ pada grafik dan nilai sumbu $Y=0$. Artinya tanpa perubahan pendapatan masyarakat mengkonsumsi telur (C) sebanyak 3,199 gr atau $0,003 \mathrm{~kg}$.

Nilai koefisien regresi dari pendapatan sebesar 0,201 (b) artinya bila pendapatan naik satu rupiah maka konsumsi telur naik sebesar 0,201 gr atau $0,0002 \mathrm{~kg}$. Setiap peningkatan pendapatan Rp 1000 maka konsumsi telur meningkat sebesar 201 gr.

Hasil uji statistik menunjukkan bahwa uji $t_{\text {hitung }}>t_{\text {tabel. }}$ Nilai $t_{\text {hitung }}$ yang diperoleh adalah 1,346 taraf signifikan 0,188 menunjukkan bahwa pendapatan berpengaruh nyata terhadap konsumsi telur di Kecamatan Siau Barat. Artinya semakin tinggi pendapatan, kecenderungan masyarakat dalam mengkonsumsi telur akan meningkat pula. Penelitian Wahyuningsih, et al(2008)menunjukkan bahwa pendapatan berpengaruh nyata terhadap konsumsi telur ayam di Jawa Timur. Hasil ini juga ditunjang oleh penelitian Weol (2014)yang menunjukkan bahwa pendapatan berpengaruh nyata terhadap konsumsi telur.

\section{KESIMPULAN}

Berdasarkan hasil penelitian dapat disimpulkan:

1. Hasil uji statistik menunjukkan bahwa nilai $t_{\text {hitung }}$ yang diperoleh sebesar 4,201 taraf signifikan 0,000. Uji $t_{\text {hitung }}>$ uji $t_{\text {tabel }}$ artinya secara statisik pendapatan berpengaruh nyata terhadap konsumsi daging ayam.

2. Hasil uji statistik menunjukkan bahwa nilai $t_{\text {hitung }}$ yang diperoleh adalah 2,757 pada taraf siginfikan 0,010. Uji $t_{\text {hitung }}>t_{\text {tabel }}$ artinya secara statistik perubahan pendapatan berpengaruh nyata terhadap perubahan konsumsi daging babi.

3. Hasil uji statistik menunjukkan bahwa nilai $\mathrm{t}_{\text {hitung }}$ yang diperoleh adalah 1,346 taraf signifikan 0,188. Uji $t_{\text {hitung }}>t_{\text {tabel }}$ artinya secara statistik pendapatan berpengaruh nyata terhadap 
konsumsi telur di Kecamatan Siau Barat.

\section{SARAN}

Perlu dilakukan penelitian lebih lanjut tentang konsumsi protein hewani beserta faktor-faktor yang mempengaruhinya, karena selain faktor pendapatan masih ada faktor lain yang mempengaruhi konsumsi daging dan telur antara lain pendidikan, harga, pola konsumsi masyarakat, adat-istiadat dan lain sebagainya.

\section{DAFTAR PUSTAKA}

Akbar, S.P dan H. Usman. 2000. Metode Penelitian Sosial. Bumi Aksara. Jakarta.

Ambat, A.G. 2011. Analisis Konsumsi Daging di Kecamatan Tikala Kota Manado. Skripsi. Fakultas Peternakan UNSRAT. Manado.

Cahyani, G.I.2008. Analisis Faktor Sosial Ekonomi Keluarga terhadap Keanekaragaman Konsumsi Pangan Berbasis Agribisnis di Kabupaten Banyumas.Tesis. Program Magister Agribisnis Program Pasca Sarjana. Universitas Diponegoro. Semarang.

Dinas Pertanian dan Peternakan SULUT. 2011. Laporan Dinas Pertanian dan Peternakan Provinsi Sulawesi Utara, Manado.

Elly, F.H., M.A.V. Manese, I.D.R. Lumenta, dan N.M. Santa. 2013. Analisis Konsumsi Pangan Produk Peternakan Rumahtangga Pesisir Pantai di Kabupaten Minahasa Selatan. p: 123-129. http://lppm.unmas.ac.id/wp-
content/uploads/2014/06/20-FEMIH.ELLY_I.D.R.LUMENTAKL1.pdf. Diakses 19 Maret 2015.

Giang, R.R. 2013. Pengaruh Pendapatan Terhadap Konsumsi Buruh Bangunan di Kecamatan Pineleng. Jurnal EMBA Vol 1 (3) : 248-256.

Osak, R.A.F., V.V.J. Panelewen., J. Pandey dan I.D.R. Lumenta. 2014. Pengaruh Pendapatan Rumahtangga terhadap Konsumsi Daging (Sapi, Babi dan Ayam) di Desa Sea I Kecamatan Pineleng. Jurnal Zootek Vol 34 (2) : 10-17.

Pontoh, O. 2011. Pengaruh Tingkat Pendapatan terhadap Pola Konsumsi Nelayan di Kecamatan Tengah Kabupaten Minahasa Selatan, Sulawesi Utara, Pacific Journal Vol 1 (5) : 1038-1040.

Soedjana, T.D. 1996. Perkembangan Konsumsi Daging dan Telur Ayam di Indonesia. Media Komunikasi dan Informasi Pangan, Agribisnis Unggas. No. 29 : 35-44.

Sugiarto, T., Herlambang, Bugiarto, R. Sudjan dan S. Kelana. 2002. Ekonomi Mikro (Sebuah Kajian Komprehensif). Gramedia. Jakarta.

Wahyuningsih, R., S.M. Kiptiyah dan H.M.I. Semaoen. 2008.Analisis Permintaan Telur Ayam di Jawa Timur. Jurnal Agritek Vol 16 (11) : 2054-2069.

Weol, E.F., B. Rorimpandey., G.D. Lenzun dan E.K.M. Endoh. 2014. Analisis Pengaruh Pendapatan Rumah Tangga terhadap Konsumsi Daging dan Telur di Kecamatan Suluun Tareran Kabupaten Minahasa Selatan. Jurnal Zootek Vol 34 (1) : 37-47.

Yusri. J. 2012. Pengaruh Variabel Ekonomi dan Karakteristik Ibu Rumahtangga Terhadap Konsumsi Daging Sapi, Daging Broiler dan 
Telur Ayam Ras Rumahtangga

Kota Padang. Indonesian Jurnal of Agricultural Economics (IJAE) Vol 3 (1) : 59-70. 